\title{
PERANCANGAN SISTEM INFORMASI ADMINISTRASI LELANG KENDARAAN PADA PT BALAI LELANG MEGATAMA
}

\author{
Nadia Hana Sabila', Cahyani Budihartanti² \\ Program Studi Sistem Informasi STMIK Nusa Mandiri, \\ Jl. Damai No.8 Warung Jati Barat (Margasatwa) Jakarta Selatan \\ E-mail: nadiahana14@gmail.com, cahyani.cbh@nusamandiri.ac.id
}

\begin{abstract}
Abstraksi
Dalam era globalisasi sekarang ini, teknologi informasi semakin maju yang menuntut kecepatan dan ketepatan dalam mengelola data serta informasi yang dihasilkan. Pengolahan data yang modern sangatlah dibutuhkan, yaitu suatu peralatan yang mampu mengolah berbagai macam data dengan cepat. PT Balai Lelang Megatama adalah perusahaan yang bergerak di bidang lelang kendaraan bermotor. Sistem administrasi lelang yang sedang berjalan di PT Balai Lelang Megatama saat ini masih dilakukan secara manual. Proses pengisian formulir peserta lelang, pembuatan kwitansi sampai pembuatan laporan masih menggunakan sistem yang konvensional. Sehingga memungkinkan terjadi kesalahan pada saat proses transaksi, kurang akuratnya laporan yang dibuat dan keterlambatan dalam pencarian data-data yang diperlukan. Sehubungan dengan permasalahan tersebut, maka muncul gagasan untuk membuat suatu sistem aplikasi desktop menggunakan bahasa pemrograman Netbeans IDE 8.2 dan database menggunakan PHPMyAdmin. Dengan menggunakan sistem yang sudah terkomputerisasi diharapkan dapat tercapai suatu kegiatan yang efektif dan efisien dalam menunjang aktifitas transaksi administrasi pada PT Balai Lelang Megatama.
\end{abstract}

Kata Kunci : Sistem Informasi, Administrasi, Sistem Administrasi Lelang

\begin{abstract}
In the current era of globalization, increasingly advanced information technology that demands speed and accuracy in managing data and information generated. Modern data processing is needed, which is a device that is able to process various kinds of data quickly. PT Balai Lelang Megatama is a company engaged in the field of motor vehicle auctions. The auction administration system currently underway at PT Balai Lelang Megatama is still being done manually. The process of filling in the bidders' forms, making receipts to making reports still uses the conventional system. So that it allows errors to occur during the transaction process, inaccurate reports made and delays in searching the data needed. In connection with these problems, the idea arose to create a desktop application system using the Netbeans IDE 8.2 programming language and the database using PHPMyAdmin. By using a computerized system that is expected to be achieved an effective and efficient activity in supporting administrative transaction activities at PT Balai Lelang Megatama.
\end{abstract}

Keywords: Information Systems, Administration, Auction Administration System

\section{Pendahuluan}

PT. Balai Lelang Megatama adalah perusahaan yang bergerak di bidang penjualan kendaraan second hand dan telah beroperasi sejak tahun 2012 yang terletak di Jalan Raya Kalimalang No.19, Duren Sawit, Jakarta Timur. Sadar bahwa bisnis otomotif bukan hanya melayani penjualan kendaraaan baru, maka di bentuk layanan transaksi penjualan kendaraan second hand dengan sistem lelang.

Proses transaksi yang di lakukan pada PT. Balai Lelang Megatama adalah dengan melalui arena lelang terbuka. Berbeda dengan cara tradisional, menjual kendaraan melalui lelang terbuka jauh lebih mudah. Cukup dengan mengisi formulir keikutsertaan, kendaraan akan di catat dan di ikutsertakan 
dalam lelang yang akan diadakan secara periodik.

Sistem administrasi pada PT Balai Lelang Megatama masih menggunakan sistem yang konvensional, dan mempunyai beberapa kendala yaitu: proses pengisian formulir keikutsertaan masih menggunakan media kertas sehingga bagian administrasi harus melakukan pencatatan secara berulang setiap event lelang. Selain itu, proses pembayaran juga masih di hitung secara manual yang memungkinkan adanya kesalahan dalam perhitungan total yang harus di bayarkan oleh pemenang lelang. Dan pencatatan laporan juga masih menggunakan aplikasi Microsoft Excel yang dapat menimbulkan terjadinya proses manipulasi data.

Hal tersebut tentunya akan menimbulkan pengaruh yang tidak baik terhadap kelancaran transaksi dan pembuatan laporan. Penggunaan sistem komputerisasi dalam melakukan pengolahan data penjualan diharapkan dapat membantu memecahkan masalah yang terjadi, menurut Oktavianus dalam (Ibnu, Mulyani, \& Safitri, 2019).

Berdasarkan penjabaran di atas, dibutuhkan sebuah program aplikasi yang dapat mempermudah proses transaksi sehingga dapat mengurangi kesalahan yang tidak di perlukan, menurut (Ibnu et al., 2019) .

Untuk mengatasi kendala-kendala tersebut maka penulis mengambil pokok permasalahan dengan judul: "Perancangan Sistem Informasi Administrasi Lelang Kendaraan Berbasis Desktop Pada PT. Balai Lelang Megatama".

\section{Metode Penelitian}

\section{Teknik Pengumpulan Data}

A. Observasi

Penulis melakukan pengamatan langsung terhadap kegiatan yang berhubungan dengan masalah yang diambil. Hasil dari pengamatan tersebut langsung dicatat oleh penulis dan dari kegiatan observasi ini dapat diketahui kesalahannya atau proses dan kegiatan tersebut. Penulis melakukan pengamatan langsung di kantor pusat PT. Balai Lelang Megatama di Jalan Raya Kalimalang No.19, Duren Sawit, Jakarta Timur yang dimulai pada tanggal 2 September 2019 sampai dengan tanggal 27 September 2019.

B. Wawancara

Suatu bentuk metode riset dengan mengajukan beberapa pertanyaan terhadap orang yang mempunyai peran penting pada objek penelitian penulis. Penulis melakukan wawancara secara langsung kepada Ibu Agustin Dwi Sartika selaku bagian Koordinator Administrasi di PT. Balai Lelang Megatama.

C. Studi Pustaka

Selain melakukan kegiatan observasi dan wawancara penulis juga melakukan studi kepustakaan melalui referensi buku bacaan dan jurnal yang erat kaitannya dengan penulisan tugas skripsi ini.

\section{Model Pengembangan Sistem}

A. Analisa Kebutuhan Software Menganalisa semua kebutuhan yang di butuhkan termasuk dokumen dan interface yang diperlukan guna menentukan solusi piranti lunak (software) yang diperlukan yang akan digunakan sebagai proses komputerisasi sistem. Dalam hal ini dilakukan analisa dan pengumpulan data kebutuhan pengguna dalam sistem administrasi lelang. Pengguna membutuhkan aplikasi yang dapat mempermudah dalam proses transaksi administrasi lelang.

B. Desain

Mendefinisikan kebutuhan sistem yang terkait dengan pengembangan aplikasi terkait rancangan database, software architecture dan user interface yang akan dibuat. Dalam membuat program ini, rancangan database didukung dengan pembuatan ERD (Entitiy Relationship Diagram). Sedangkan software architecture penulis menggunakan UML (Unified Modeling Language). Penggunaan UML (Unified Modeling Language) dimaksud menjelaskan lebih terperinci dalam rancangan pembuatan program dan rancangan database, menurut (Dharmawan, Purwaningtias, \& Risdiansyah, 2018). Dan untuk user interface pada aplikasi ini memungkinkan pengguna untuk dapat mengelola data administrasi seperti, menginput data peserta lelang, memproses pembayaran dan membuat laporan.

C. Code Generation

Menentukan bahasa pemrograman yang akan digunakan. Pada tahap ini MySQL digunakan untuk membuat 
database yang ditulis menggunakan bahasa pemrograman NetBeans IDE 8.2. Bahasa yang digunakan adalah bahasa pemrograman berbasis object.

D. Testing

Mendeskripsikan proses pengujian yang akan dilakukan dengan menggunakan blackbox testing.

Menurut (Dharmawan et al., 2018) blackbox testing adalah pengujian yang dilakukan hanya mengamati hasil eksekusi melalui data uji dan memeriksa fungsional dari perangkat lunak.

E. Support

Untuk melakukan pengembangan terhadap sistem yang sudah dibuat, penulis akan terus melakukan update serta penyempurnaan pada program ini, baik dari segi hardware maupun software. Selain itu jaringan intranet juga dibutuhkan apabila perusahaan menginginkan program tersebut dapat diakses lebih dari satu computer, menurut (Dharmawan et al., 2018).

\section{Hasil dan Pembahasan}

\subsection{Proses Bisnis}

Adapun proses bisnis yang sedang berjalan pada PT. Balai Lelang Megatama adalah sebagai berikut :

1. Proses pendaftaran lelang

Setelah melakukan pengecekan kendaraan, peserta lelang dapat langsung melakukan pendaftaran dengan menyerahkan fotocopy KTP, mengisi formulir dan menyerahkan uang jaminan sebesar Rp 1.000.000,- untuk 1 lot motor dan Rp 5.000.000,- untuk 1 lot mobil. Setelah peserta lelang melakukan pendaftaran dan menyerahkan uang jaminan, bagian administrasi membuat kwitansi jaminan sebanyak 2 rangkap. Rangkap pertama diserahkan ke peserta lelang beserta NIPL (nomor induk peserta lelang) dan rangkap kedua diarsipkan dengan formulir, fotocopy KTP, dan NIPL.

2. Proses pengembalian jaminan

Jika peserta lelang sudah mengikuti proses lelang tetapi tidak ditetapkan sebagai pemenang lelang, maka peserta lelang wajib menyerahkan kwitansi jaminan beserta NIPL ke bagian administrasi untuk dibuatkan tanda terima penyerahan uang jaminan.

3. Proses pelunasan unit
Peserta yang telah melaksanakan lelang kendaraan dan telah ditetapkan sebagai pemenang lelang, akan diberikan BAP (berita acara pemenang lelang) oleh juru lelang. Bagian administrasi mulai memproses pelunasan unit setelah pemenang menyerahkan BAP, kwitansi jaminan, dan bukti pembayaran (sesuai dengan harga unit yang ditetapkan pada saat lelang). Setelah proses pelunasan selesai, bagian administrasi menyerahkan ke pemenang kwitansi pelunasan dan unit lelang yang dimenangkan.

4. Proses pembuatan laporan penjualan per event

Berdasarkan data pemenang lelang bagian administrasi mulai mencatat laporan penjualan per event lelang. Laporan tersebut diserahkan ke bagian koordinator administrasi dan asisten manajer.

\subsection{Activity Diagram}

Activity Diagram menggambarkan workflow (aliran kerja) atau aktivitas dari sebuah sistem atau proses bisnis menurut (Hendini, 2016).

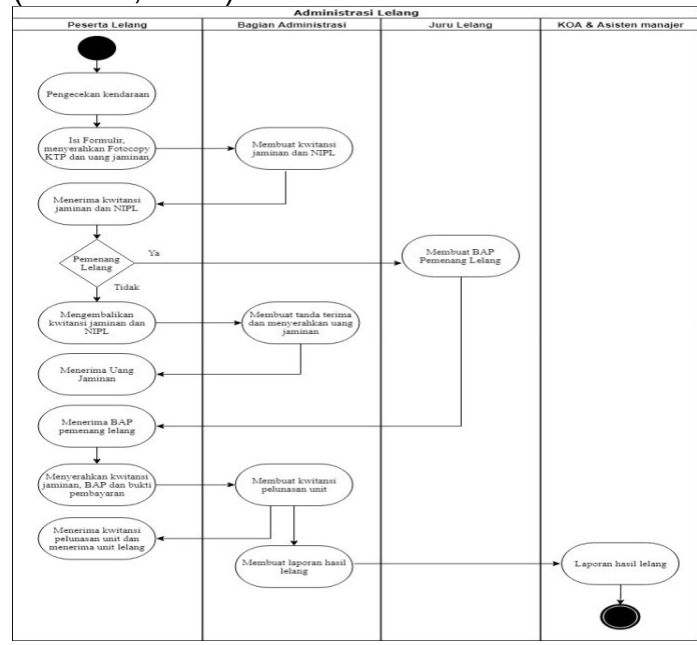

\section{Gambar 4.I Activity Diagram Proses Administrasi Lelang PT. Balai Lelang Megematama}

\subsection{Use Case Diagram}

Use case digunakan untuk mengetahui fungsi apa saja yang ada di dalam sistem informasi dan siapa saja yang berhak menggunakan fungsi-fungsi tersebut menurut (Hendini, 2016). Berikut adalah use case dari sistem informasi administrasi lelang pada PT. Balai Lelang Megatama yang terbagi menjadi 2 kegiatan yaitu admin dan koa (coordinator administrasi). 
a. Use Case Diagram Halaman Admin

Admin dapat mengelola data peserta lelang, mengelola data jaminan lelang, mengelola data pengembalian jaminan, melakukan transaksi pelunasan unit dan mengelola laporan.

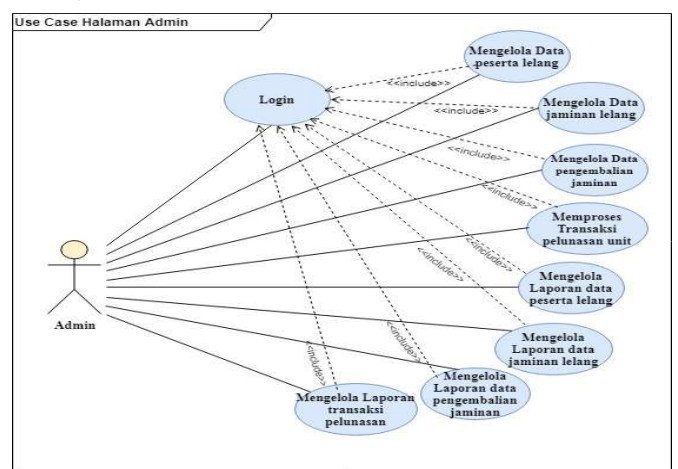

Gambar 4.2 Use Case Diagram Halaman Admin

\section{b. Use Case Diagram Halaman KOA}

KOA dapat mengelola data unit, mengelola data user, melihat laporan unit, laporan user dan laporan transaksi lelang.

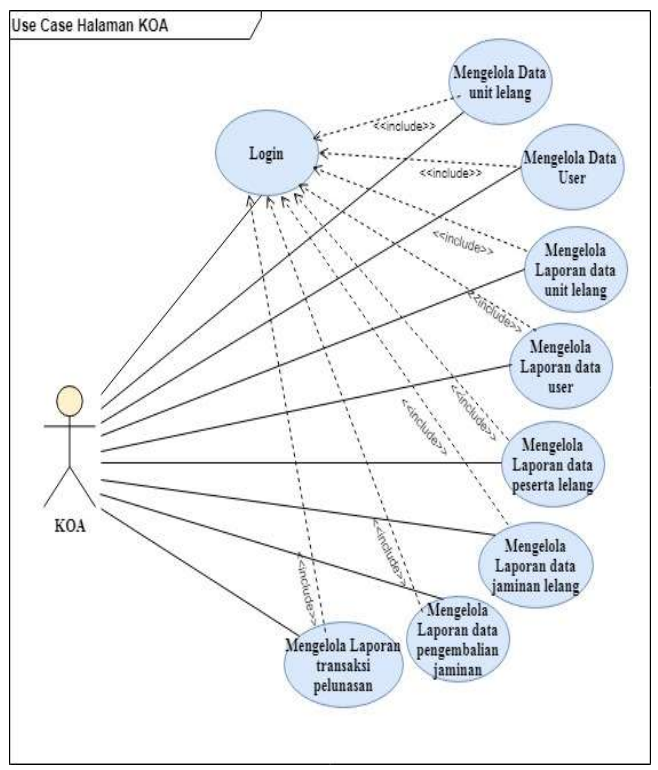
KOA

Gambar 4.3 Use Case Diagram Halaman

\subsection{Entity Relationship Diagram (ERD)}

Menurut (Fridayanthie \& Mahdiati, 2016) menjelaskan bahwa, "ERD (Entity Relationship Diagram) adalah model teknik pendekatan yang menyatakan atau menggambarkan hubungan suatu model. Didalam hubungan ini tersebut dinyatakan yang utama dari ERD adalah menunjukan objek data (Entity) dan hubungan (Relationship), yang ada pada Entity berikutnya".

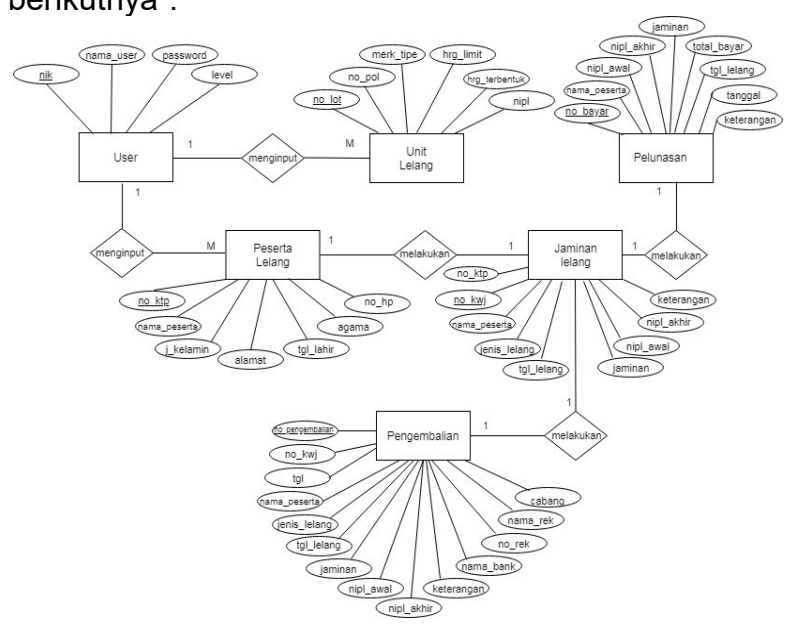

\section{Gambar 4.4 Entity Relationship \\ Diagram(ERD) Administrasi Lelang}

\subsection{Component Diagram}

Component Diagram menggambarkan struktur dan hubungan antar piranti lunak, termasuk ketergantungan diantaranya. Component Diagram juga dapat berupa interface yang berupa kumpulan layanan yang disediakan oleh komponen untuk komponen lainnya (Fridayanthie, 2017).

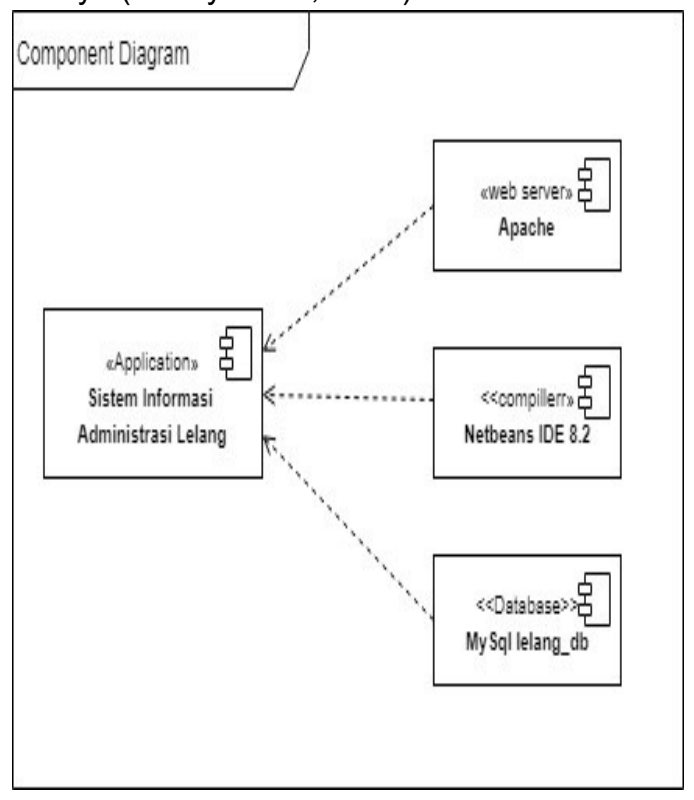

Gambar 4.5. Component Diagram Sistem Administrasi Lelang 


\subsection{Deployment Diagram}

Deployment Diagram digunakan untuk menggambarkan detail bagaimana komponen disusun di infrastruktur sistem.

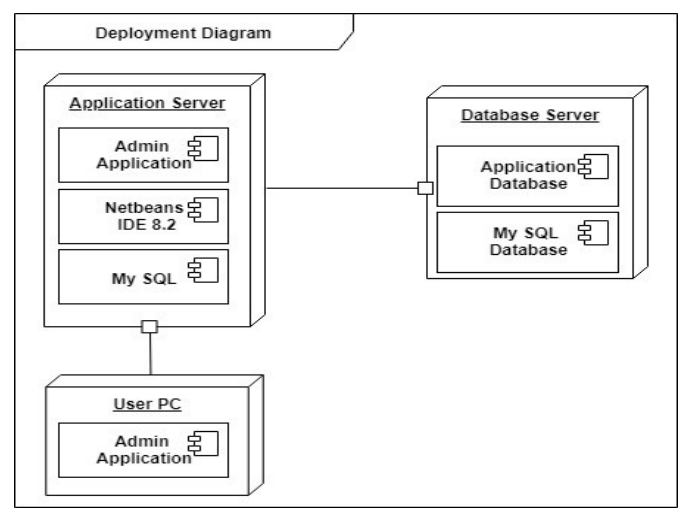

Gambar 4.6 Deployment Diagram Sistem Administrasi Lelang

\subsection{User Interface}

Berikut adalah tampilan-tampilan pada sistem informasi administrasi lelang pada PT. Balai Lelang Megatama

1. Tampilan Form Login

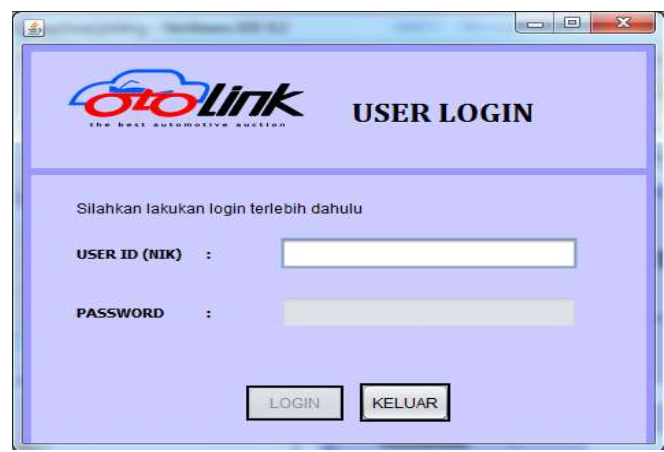

Gambar 4.7 Tampilan Form Login

2. Tampilan Form Menu Utama Admin

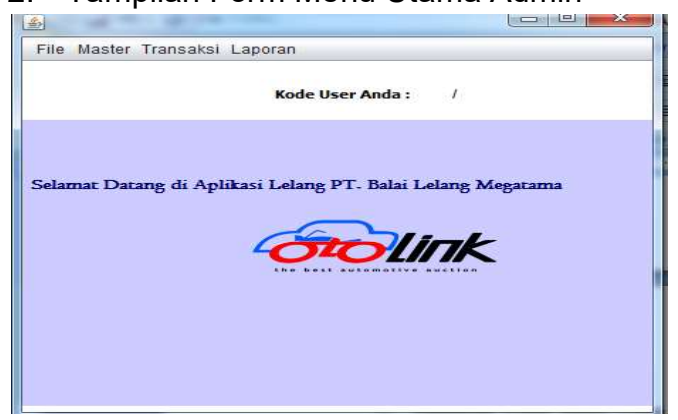

Gambar 4.8 Tampilan Form Menu Utama Admin
3. Tampilan Form Menu Utama KOA

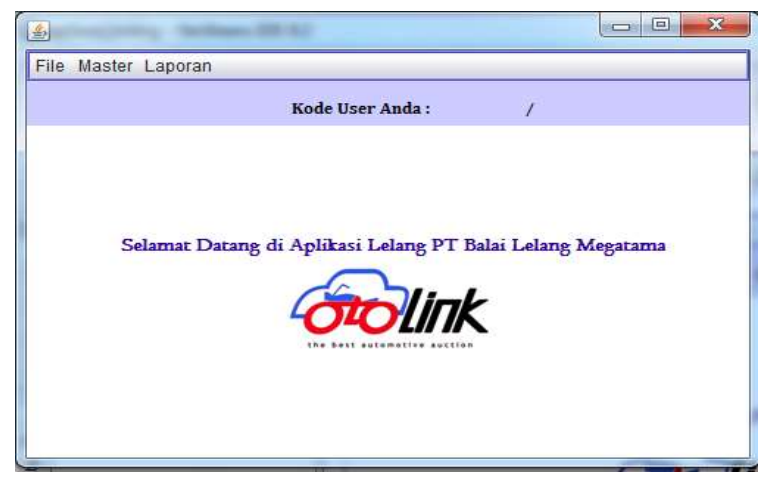

\section{Gambar 4.9 Tampilan Form Menu Utama} KOA

4. Tampilan Form Pendaftaran Peserta Lelang

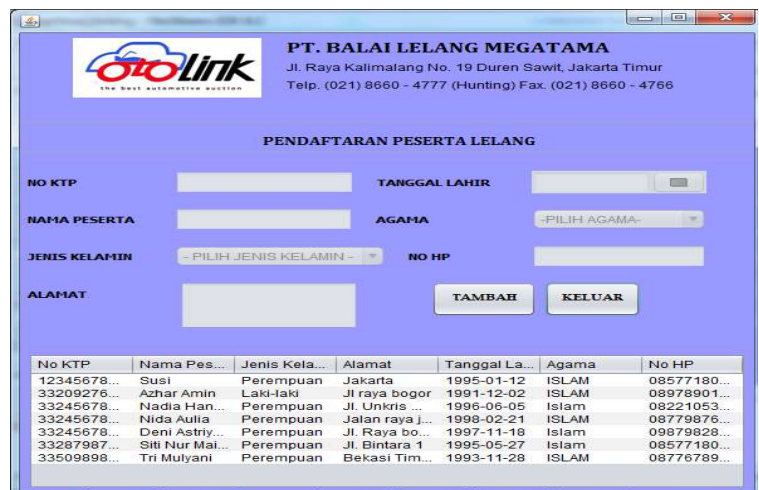

\section{Gambar 4.10 Tampilan Form Pendaftaran Peserta Lelang}

5. Tampilan Form Jaminan

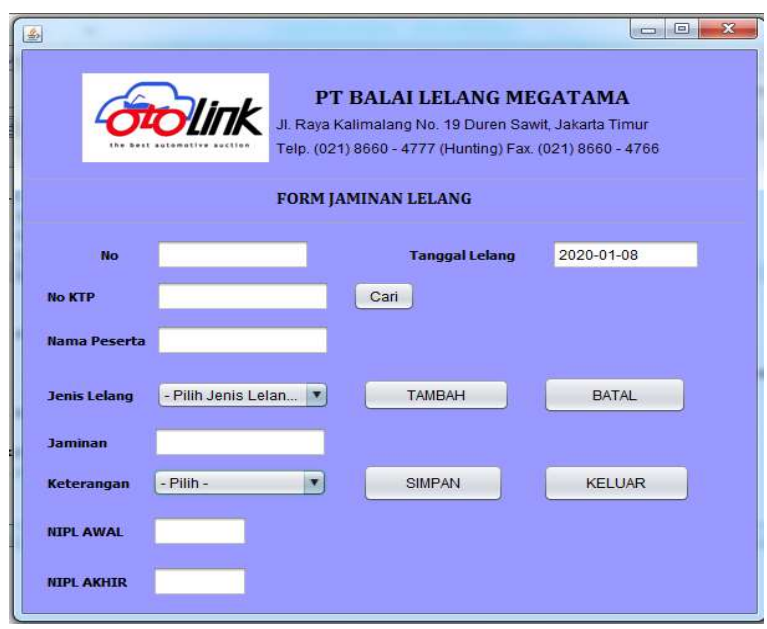

Gambar 4.11 Tampilan Form Jaminan 
6. Tampilan Form Pengembalian Jaminan

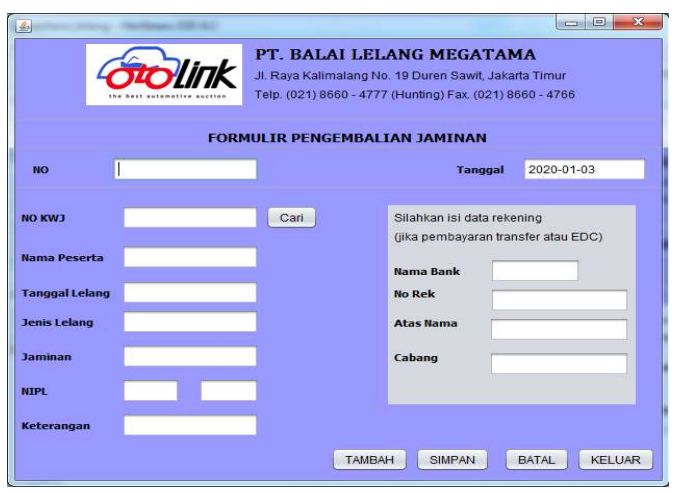

\section{Gambar 4.12 Tampilan Form Pengembalian Jaminan}

7. Tampilan Form Pelunasan Unit

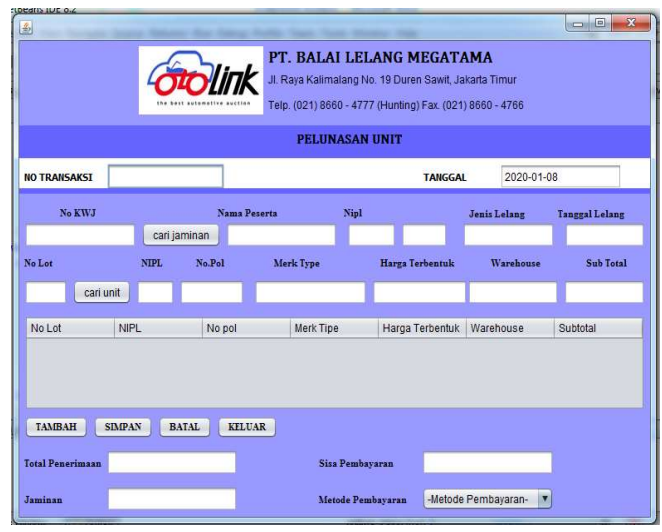

Gambar 4.13 Tampilan Form Pelunasan

\section{Unit}

8. Tampilan Form Data Unit Lelang

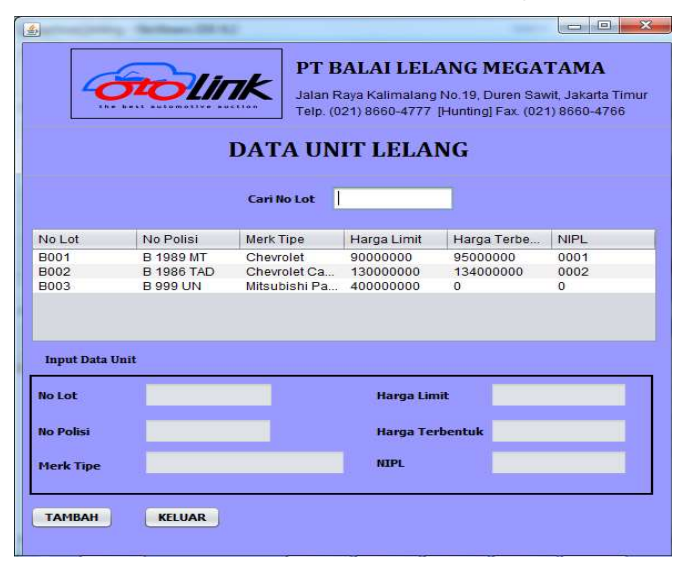

Gambar 4.14 Tampilan Form Data Unit
9. Tampilan Form Data User

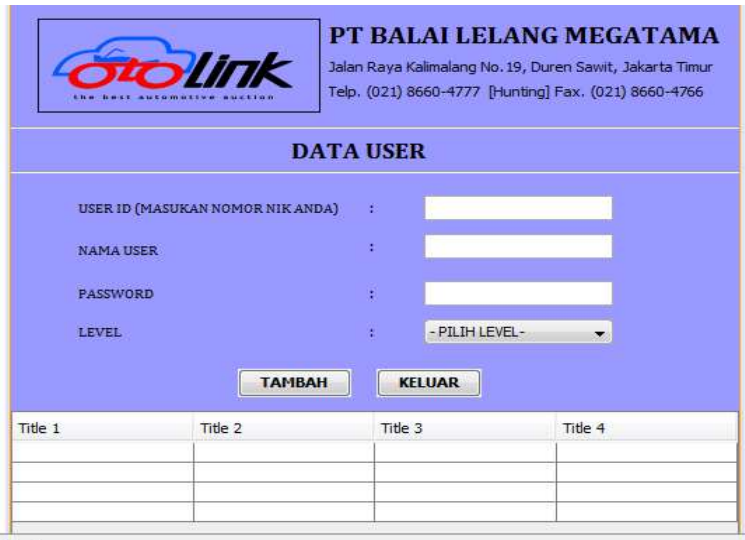

\section{Gambar 4.15 Tampilan Form Data User}

\subsection{Testing}

Pengujian yang dilakukan adalah menggunakan pengujian blackbox yang hanya mengamati hasil eksekusi mengui dan memeriksa fungsional dari perangkat lunak menurut (Fridayanthie, 2017).

\begin{tabular}{|c|c|c|c|c|c|}
\hline No & $\begin{array}{l}\text { Skenario } \\
\text { Pengujian }\end{array}$ & Test Case & $\begin{array}{l}\text { Hasil yang } \\
\text { diharapkan }\end{array}$ & $\begin{array}{c}\text { Hasil } \\
\text { Pengujian }\end{array}$ & Kesimpulan \\
\hline 1 & \begin{tabular}{|l} 
Mengisi \\
data userid \\
dengan salah \\
dan \\
mengosongkan \\
data password, \\
lalu \\
mengklik \\
tombol \\
enter
\end{tabular} & $\begin{array}{l}\text { userid (salah) } \\
\text { password } \\
\text { (kosong) }\end{array}$ & \begin{tabular}{|l|} 
Sistem akan \\
menolak akses \\
login dan \\
menampilkan \\
pesan "User ID \\
salah!"
\end{tabular} & $\begin{array}{l}\text { Sesuai } \\
\text { Harapan }\end{array}$ & Valid \\
\hline 2 & $\begin{array}{l}\text { Mengisi data } \\
\text { userid dengan } \\
\text { benar dan data } \\
\text { password } \\
\text { dengankondisi } \\
\text { salah, lalu } \\
\text { klik tombol } \\
\text { login }\end{array}$ & \begin{tabular}{|l|} 
userid (benar) \\
password(salah)
\end{tabular} & \begin{tabular}{|l} 
Sistem akan \\
menolak akses \\
login dan \\
menampilkan \\
pesan \\
"Password \\
salah!"
\end{tabular} & $\begin{array}{l}\text { Sesuai } \\
\text { Harapan }\end{array}$ & Valid \\
\hline 3 & \begin{tabular}{|l} 
Mengisi data \\
userid dan \\
data password \\
dengan benar, \\
laluklik \\
tombollogin \\
\end{tabular} & \begin{tabular}{|l|} 
userid (benar) \\
password(benar)
\end{tabular} & $\begin{array}{l}\text { Sistem akan } \\
\text { menerima akses } \\
\text { login dan } \\
\text { kemudian } \\
\text { langsung } \\
\text { menampilkan } \\
\text { formmenu } \\
\text { utama }\end{array}$ & $\begin{array}{l}\text { Sesuai } \\
\text { Harapan }\end{array}$ & Valid \\
\hline
\end{tabular}

Gambar 4.16 Black Box Testing Form

\section{Login}

Lelang 


\section{4. Kesimpulan}

Berdasarkan hasil riset yang penulis lakukan mengenai sistem informas iadministrasi lelang pada PT Balai Lelang Megatama masih menggunakan sistem secara manual, dimana masih terdapat kekurangan dalam memproses transaksi, keterlambatan pembuatan laporanserta penyimpanan data yang kurang efektif dan efisien. Dengan keadaan yang demikian maka dibutuhkan sebuah sistem informasi berbasis komputer untuk mempermudah proses transaksi administrasi lelang.

Secara umum kesimpulan penulis mengenai sistem tersebut akan dijelaskan sebagai berikut:

1. Dengan sistem administrasi lelang yang terkomputerisasi pada PT Balai Lelang Megatama, proses transaksi dilakukan secara cepat dan tepat sehingga terhindar dari kesalahan dalam pencatatan dan perhitungan.

2. Dengan menggunakan sistem yang terkomputerisasi diharapkan dapat membatu proses kerja, seperti mengolah data yang cukup banyak serta menghasilkan data laporan yang benar, akurat dan tepat waktu. Sehingga menghasilkan informasi yang bermutu dalam pengambilan keputusan.

\section{Referensi}

Adhawiyah, Y., Kumaladewi, N., \& Caturutami, M. (2017). Rancang Bangun Sistem Informasi Penilaian Kinerja Pegawai Menggunakan Metode Psycological Appraisal (StudiKasus:Kantor Wilayah Kementerian Agama DKI Jakarta) Yunita. Studia Informatika, 10(2), 119126. Retrieved from http://journal.uinjkt.ac.id/index.php/ sisteminformasi/article/view/7759/4310

Afifah, I. I. N., \& Supriyatna. (2018). Sistem Informasi Penjualan Busana Pengantin Pada Tutut Manten Yogyakarta. Jurnal Speed, 10(1), 1-6. Retrieved from https://repository.nusamandiri.ac.id/inde x.php/unduh/item/2052/Jurnal-SPTTutut-Manten.pdf

Ahmad, L., \& Munawir. (2018). Sistem Informasi Manajemen (1st ed.; Syariffudin, ed.). Retrieved from https://books.google.co.id/books?id=Jr2 XDwAAQBAJ\&printsec $=$ frontcover\&dq=buku+sistem+informasi+ manajemen+lukman+ahmad\&hl=en\&sa
$=X \& v e d=0$ ahUKEwilz6iiqtzlAhWMaCsK HSTwAQEQ6AEIKDAA\#v=onepage\&q= buku sistem informasi manajemen lukman ahmad\&f=true

Akil, I. (2016). Rekayasa Perangkat Lunak Dengan Model Unified Process Studi Kasus: Sistem Informasi Journal. Jurnal Pilar Nusa Mandiri, 12(1), 1-11. Retrieved from https://media.neliti.com/media/publicatio ns/227534-rekayasa-perangkat-lunak dengan-model-un-8ed052ca.pdf

Anggraeni, E. Y., \& Irviani, R. (2017). Pengantar Sistem Informasi (E. Risanto, ed.). Retrieved from https://books.google.co.id/books?id=8V NLDwAAQBAJ\&printsec

$=$ frontcover $\& d q=$ buku+sistem+informasi \&hl=en\&sa=X\&ved=0ahUKEwi2uc2Q_J 3iAhWHto8KHQHuCRYQ6AEIKjAA\#v=o nepage $\& \mathrm{q}=$ bukusisteminformasi $\& \mathrm{f}=$ false

Astuti, R. W., Fauziah, S., Yudhistira, \& Noviriandini, A. (2019). Rancang Bangun Sistem Informasi Akuntansi Pembelian Bahan Baku Secara Kredit. Jurnal Akrab Juara, 4(1), 63-77. Retrieved from http://akrabjuara.com/index.php/akrabju ara /article/view/440

Bastian, A., Prasetyo, T. F., \& Kurniati, N. (2017). Rancang Bangun Sistem Informasi Manajemen Peternak Ayam pada Koperasi Sinar Mulya Menggunakan Microsoft Visual Basic 2010. Net. Studia Informatika: Jurnal Sistem Informasi, 10(2), 135-143. Retrieved from http://journal.uinjkt.ac.id/index.php/siste minformasi/article/ view/7761/4312

Dharmawan, W. S., Purwaningtias, D., \& Risdiansyah, D. (2018). Penerapan Metode SDLC Waterfall Dalam Perancangan Sistem Informasi Administrasi Keuangan Berbasis Desktop. Jurnal Khatulistiwa Informatika, VI(2), 159-167. Retrieved from https://media.neliti.com/media/publicatio ns/280425-penerapan-metode-sdlcwaterfall-dalam-pe-4153fab1.pdf

Ibnu, R., Mulyani, A. S., \& Safitri, A. S. (2019). Rancang Bangun Sistem Informasi Penjualan Secara Online PT Picotel Nusantara. INTI NUSA MANDIRI, 14(1), 49-56. Retrieved from https://repository.nusamandiri.ac.id/inde x.php/repo/viewitem/ 10323

Firmansyah, Y., \& Udi, U. (2018). Penerapan Metode SDLC Waterfall Dalam 
Pembuatan Sistem Informasi Akademik Berbasis Web Studi Kasus Pondok Pesantren Al-Habib Sholeh Kabupaten Kubu Raya, Kalimantan Barat. Jurnal Teknologi Dan Manajemen Informatika, 4(1), 185-191. https://doi.org/10.26905/jtmi.v4i1.1605

Fridayanthie, E. W., \& Mahdiati, T. (2016). Rancang Bangun Sistem Informasi Permintaan ATK Berbasis Intranet (Studi Kasus: Kejaksaan Negeri Rangkasbitung). Jurnal Khatulistiwa Informatika, IV(2),126-138. https://doi.org/https://doi.org/10.31294/jk i.v4i2.1264.g1029

Hendini, A. (2016). Pemodelan UML Sistem Informasi Monitoring Penjualan Dan Stok Barang (Studi Kasus: Distro Zhezha Pontianak). Jurnal Khatulistiwa Informatika, 4(2), 107-116. https://doi.org/https://doi.org/10.31294/jk i.v4i2.1262.g1027

Hutahaean, J. (2014). Konsep Sistem Informasi (1st ed.). Retrieved from https://books.google.co.id/books?id=o8L jCAAAQBAJ\&printsec $=$ frontcover $\& \mathrm{dq}=\mathrm{k}$ onsep+sistem+informasi\&hl=en\&sa $=X \&$ ved=0ahUKEwj8rsjr9zIAhUIfSsKHSzuC scQ6AEIKDAA\#v=onepage $\& \mathrm{q}=$ konsepsi stem informasi\& $\mathrm{f}=$ true

Muslihudin, M., \& Oktafianto. (2016). Analisis dan Perancangan Sistem Informasi Menggunakan Model Terstruktur dan UML (1st ed.; A. Pramesta, ed.). Retrieved https://books.google.co.id/books? id=2S U3DgAAQBAJ\&printsec=frontcover $\& d q=a n a l i s i s+d a n+$ perancangan+sistem +informasi+menggunakan+model+terstr uktur+dan+uml\&hl=en\&sa $=X \& v e d=0 a h$ UKEwjoiejcg93IAhWBILcAHVqWAOQQ 6AEIKDAA\# $v=$ onepage $\& q \& f=$ true

Musyafa, A. (2017). Perancangan Aplikasi Administrasi Sekolah Berbasis Desktop. Jurnal Informatika Universitas Pamulang, 2(4), 166-173. https://doi.org/10.32493/informatika.v2i4 .1436

Setiawan, A., Soelaiman, R., \& Akbar, R. J. (2017). Rancang Bangun Aplikasi Pelelangan Online (E-Auction) berbasis Perangkat Bergerak Android. Jurnal Teknik ITS, 6(2), 2-6. https://doi.org/10.12962/j23373539.v6i2. 24130

Rusli, M., Rinartha, I. K., \& Atmojo, Y. P. (2016). Belajar Pemrograman Java Dengan Netbeans sebuah pengantar (1st ed.; P. Christian, ed.). Retrieved from

https://books.google.co.id/books?id=1x DDwAAQBAJ\&printsec $=$ frontcover \&dq= netbeans\&hl=en\&sa $=X \& v e d=0 a h U K E w$ iTIZzjkN3IAhXJXisKHcKcAqEQ6AEIOD $A C \# v=$ onepage\&q\&f=true

Setiawan, A., Soelaiman, R., \& Akbar, R. J. (2017). Rancang Bangun Aplikasi Pelelangan Online (E-Auction) berbasis Perangkat Bergerak Android. Jurnal Teknik ITS, 6(2), 2-6. https://doi.org/10.12962/j23373539.v6i2. 24130

Tista, A. (2013). Perkembangan Sistem Lelang Di Indonesia. Al' Adl, V(10), 4670. Retrieved from https://ojs.uniskabjm.ac.id/index.php/aldli/article/view/194 1187 